\title{
Using Soil and Foliar Applications of some Fertilizers to Improve the Yield and Quality Parameters of Table Grapes (Vitis vinifera $\mathrm{L}$.
}

\author{
Hisham ABO-AHMEDEH ${ }^{1}$, Amer MHASNEH ${ }^{1}$, Hamzeh RAWASHDEH ${ }^{2 *}$ \\ ${ }^{1}$ Ajloun Extension Department, Jordan's Ministry of Agriculture, Ajloun, Jordan \\ ${ }^{2}$ National Agricultural Research Center (NARC), Directorate of Water and Soil Management Researches, \\ P.0. Box 639, Baq'a 19381, Amman, Jordan \\ * corresponding author: hamz_rawashdeh@yahoo.com
}

Bulletin UASVM series Agriculture 77(1) / 2020

Print ISSN 1843-5246; Electronic ISSN 1843-5386

DOI:10.15835/buasvmcn-agr: 2019.0016

\begin{abstract}
The objective of the current study was to investigate the effect of soil and foliar application of some fertilizers on the yield and quality of table grapes cv. Alkdarri. Soil and foliar fertilizer application treatments included a control, Ca 200 g/vine, K 150 g/vine, N 200 g/vine, Ca 30 g/L, grow more ${ }^{\text {INC }}$ fertilizer $10 \mathrm{~g} / \mathrm{L}, \mathrm{K} 20 \mathrm{~g} / \mathrm{L}$, and Cu $5 \mathrm{mg} / \mathrm{L}$. Results indicate that soil and foliar fertilizer application increases quality and quantity of table grapes compared to control treatment. The highest berry diameter, a weight of 100 berries and a size of 100 berries were obtained in vines treated with Ca $200 \mathrm{~g} / v i n e$, using the soil application method. The highest cluster weight was obtained in vines that were treated with $\mathrm{K} 150 \mathrm{~g} / \mathrm{vine}$, using the soil application method. The highest berry firmness was obtained in vines that were treated with $\mathrm{K} 20 \mathrm{~g} / \mathrm{L}$ using the foliar application method. The highest $\mathrm{pH}$ and TSS were obtained in vines treated with $\mathrm{Cu} 5 \mathrm{mg} / \mathrm{L}$, using the foliar application method. The highest fruit yield was found in vines that were treated with $150 \mathrm{~g} \mathrm{~K}$.
\end{abstract}

Keywords: soil application, foliar spray, grape, fruit yield and quality

\section{INTRODUCTION}

The common grapevine (Vitis vinifera L.) belongs to Vitaceae family, and one of the most important horticultural crops in the world. The berries are a good source of vitamins (A, B and $\mathrm{C}$ ) and minerals ( $\mathrm{Fe}, \mathrm{Ca}, \mathrm{P}, \mathrm{Mg}, \mathrm{K}$ and $\mathrm{Mn}$ ). The fruits are consumed fresh as table grapes and in processed form as raisins and fresh juice (Birjely et al., 2017, Mohamadineia et al., 2015).

Worldwide grape production contributes to about $16 \%$ of the total fruit production. The total area of grape orchards in the world covers 7.5 million hectares. In 2017, grape production was estimated at 73.3 million tons (OIV, 2018). In 2017, grapes were cultivated in Jordan on an area of 289,386 ha generating a total production 1849 $\mathrm{kg} / \mathrm{ha}$ (Department of statistics, 2019). However, production was negatively affected by several factors, including: poor soil fertility, drought, a high input of macronutrients, but a low input of micronutrients.

Plants need sufficient macro and micronutrient application in order to satisfy their needs and to produce optimum quantity and quality yield (Souri, 2016; Zivdar et al., 2016; Tohidloo et al., 2018). Deficiency in any mineral nutrient or deficiencies in several minerals can significantly inhibit crop growth and yield. When the nutrient supply is insufficient, plants may develop deficiency symptoms and reduced qualitative yield (Mengel and Kirkby, 2001; Sala and Dobrei, 2015).

Foliar application of nutrients is one of the most important practices, considering that foliar fertilization provides the stems, leaves or 
fruits directly with nutrients. The application of nutrients during diffenent growth stages can improve the nutrient balance of crops, which, in turn, leads to increased yield and improved quality (Zivdar et al., 2016).

Nutrients are commonly applied directly to the soil. The effect of fertilizers applied to the soil is sometimes reduced due to many factors, ranging from soil type to plant features and the physiological condition (Bratasevec et al., 2013).

Foliar application of fertilizers is an alternative when nutrient absence cannot be corrected by applications of fertilizers to the soil (Dehnavard et al., 2017), so it is helpful when the roots cannot provide essential nutrients (Rawashdeh and Sala, 2015). It has been shown that under variable environmental conditions and adverse soil conditions, foliar fertilization is an important and effective method of nutrient supply to plants (Sala and Dobrei, 2015; Souri and Hatamian, 2019).

In arid and semiarid regions, the rainfall is usually low and erratic, with low soil fertility, leading to decreased yield (Souri, 2016). Fertilizer application plays a pivotal role in enhancing agricultural production. However, new strategies of orchard management are required to increase fruit yield and quality. For this purpose, applying an efficient nutritional management such as soil or foliar applications of fertilizers is one of the essential practices in this region. In this context, the present study targeted the following specific objectives. (i) To study the effect of soil application of N, K and Ca fertilizer at two growth stages. (ii) To study the impact on yields of enhanced foliar application of $\mathrm{N}, \mathrm{K}, \mathrm{Ca}, \mathrm{Cu}$ fertilizer at two growth stages, as well as some quality parameters of table grapes.

\section{MATERIALS AND METHODS}

The experiment was carried out during 2016 and 2017 seasons on Vitis vinifera L. cv. Alkdarri grown in a private grape farm located at Sakhra,
Ajloun Governorate, Jordan, with an average annual rainfall of about $550 \mathrm{~mm}$; the textural class of the soil was clay. Ten-year-old 'Alkdarri' grape trees generally planted at a distance of 4.0 $\mathrm{m}$ in rows spaced at $4.0 \mathrm{~m}$ were selected for the experiment. Grape trees were directed as bilateral cordons onto a single-curtain (wire) trellis system. Soil samples of about 1.3-1.5 kg were collected from two depths to determine the chemical and physical properties of the soil by using standard methods. The soil was air-dried, passed through a $2 \mathrm{~mm}$ sieve so as to obtain a more homogeneous soil sample. The physical and chemical properties of the soils are presented in Tab. 1.

The experiment was laid out in a Randomized Completely Block Design (RCBD) with eight treatments and five replications. Each experimental plot consisted of nine vines for each treatment providing one "inner" tree for monitoring and for data collection and surrounded by border trees receiving the same treatment.

Grape vines were subjected to seven treatments ( 3 soil and 4 foliar applications), along with control treatment (untreated). Soil treatments were applied with irrigation on two occasions: at the final stage of flowering (BBCH 69) and when berries begin to develop their variety-specific colour (BBCH 81). Foliar treatments were applied at the same growth stages as in soil application. The soil treatments applied contained exclusively calcium as calcium oxide $(27 \% \mathrm{Ca})$, potassium as potassium sulphate $(44 \% \mathrm{~K})$, and nitrogen as ammonium sulphate $(21 \% \mathrm{~N})$ as follows: $200 \mathrm{~g} / \mathrm{vine}$, $150 \mathrm{~g} / \mathrm{vine}$, and $200 \mathrm{~g} / \mathrm{vine}$ respectively.

Foliar treatments were applied solely as follows: Ca $30 \mathrm{~g} / \mathrm{L}$ as calcium oxide $(27 \% \mathrm{Ca})$, Grow More $^{\text {INC }}$ fertilizer $10 \mathrm{~g} / \mathrm{L}$ (containing total $\mathrm{N}=20 \%$, $\mathrm{P}_{2} \mathrm{O}_{5}=20 \%, \mathrm{~K}_{2} \mathrm{O}=20 \%, \mathrm{~B}=0.02 \%, \mathrm{Cu}=0.05 \%$, $\mathrm{Fe}=0.1 \%, \mathrm{Mn}=0.05 \%, \mathrm{Zn}=0.05 \%), \mathrm{K} 20 \mathrm{~g} / \mathrm{L}$ as potassium sulphate $(44 \% \mathrm{~K})$, and $\mathrm{Cu} 5 \mathrm{mg} / \mathrm{L}$. as $\mathrm{Cu}$-EDTA $(12 \% \mathrm{Cu})$. Foliar solutions were sprayed using a high pressure hand sprayer, one litre per

Table. 1. Some physical and chemical soil properties

\begin{tabular}{cccccccc}
\hline Depth (cm) & Texture & $\begin{array}{c}\text { EC } \\
(\mathbf{d s} / \mathbf{m})\end{array}$ & $\mathbf{p H}$ & $\begin{array}{c}\mathbf{0 . M} \\
\mathbf{( \% )}\end{array}$ & $\begin{array}{c}\mathbf{N} \\
\mathbf{( \% )}\end{array}$ & $\begin{array}{c}\mathbf{P}_{\mathbf{2}} \mathbf{O}_{5} \\
(\boldsymbol{\mu g} / \mathbf{g})\end{array}$ & $\mathbf{K}_{\mathbf{2}} \mathbf{O}_{\mathbf{5}}$ \\
\hline $0-20$ & Clay & 0.48 & 7.82 & 1.12 & 0.15 & 23.80 & 369.62 \\
\hline $20-40$ & Clay & 0.55 & 8.00 & 0.64 & 0.07 & 14.61 & 412.40 \\
\hline
\end{tabular}


vine. Tween-20 at $0.1 \%(\mathrm{v} / \mathrm{v})$ as surfactant was mixed with the foliar solution, $1 \mathrm{ml}$ per one liter, to enhance adhesion of the solution to plant foliage and an equal amount of water was applied to the control treatment. Spraying was performed in the morning (between 7.00 to $9.00 \mathrm{am}$ ). The solution was sprayed on the leaves observing uniform coverage until leaves were completely wet.

The following morphophysiological traits were measured at the stage of maturity: the cluster number per vine was counted and weighed to determine total yield per vine. Representative random samples of 10 clusters were taken from each replicate to the laboratory to determine cluster weight and cluster volume. A random sample of 100 berries per each replication was taken to determine (a) the physical properties of the fruit (berry diameter, weight, and volume of 100 berries, as well as berry firmness and (b) the chemical properties of the fruit ( $\mathrm{pH}$ and TSS). The collected data were analyzed using MSTAT-C Computer Software version 2.10 (MSTAT-C, 1991). The means differences among the treatments were compared by employing the Least Significant Difference (LSD) test at 5\% probability level.

\section{RESULTS AND DISCUSSIONS}

Cluster weight (g): Data in (Tab. 2) indicate that the highest cluster weight of $763.14 \mathrm{~g}$ was obtained in vines treated with soil application of $\mathrm{K}$ $150 \mathrm{~g} / \mathrm{vine}$ and the lowest single cluster weight of $533.11 \mathrm{~g}$ was observed in the control.
Weight of 100 berries (g): The effect of different sources of fertilizer nutrients on the weight of 100 berries was statistically significant at $\mathrm{p}<0.05$ (Tab. 2). The maximum weight of 100 berries was displayed by vines receiving soil application of Ca $200 \mathrm{~g} /$ vine fertilizer treatment, followed by vines receiving soil application of K $150 \mathrm{~g} /$ vine fertilizer treatment, while the minimum weight of 100 berries was gained by the control.

Size of 100 berries $\left(\mathrm{cm}^{3}\right)$ : Data presented in (Tab. 2) shows significant effects of different sources of fertilizer nutrients on the size of 100 berries. This results showed that soil application of Ca $200 \mathrm{~g} /$ vine has the greatest impact on the size of 100 berries, followed by vines receiving soil application of K $150 \mathrm{~g} / \mathrm{vine}$, while the smallest size of 100 berries was obtained by the control.

Berry diameter (cm): The statistical analysis of data in (Tab. 2) shows significant effects of foliar and soil application on berry diameter at $\mathrm{P}<0.05$. The maximum berry diameter was related to soil application of Ca $200 \mathrm{~g} /$ vine, followed by foliar application of $\mathrm{K} 10 \mathrm{~g} / \mathrm{L}$.

Berry firmness (g/berry): The berry firmness was significantly influenced by the application of soil and foliar fertilizers (Tab. 3). Also, berry firmness was enhanced by soil and foliar application, as follows: vines received foliar application of $\mathrm{K} 10 \mathrm{~g} / \mathrm{L}$, followed by soil application of K $150 \mathrm{~g} /$

Table. 2. Effect of soil and foliar applications of some fertilizers on some yield features of table grape cv. Alkdarri

\begin{tabular}{lcccc}
\hline \multicolumn{1}{c}{ Treatments } & $\begin{array}{c}\text { Cluster weight } \\
\mathbf{( g )}\end{array}$ & $\begin{array}{c}\text { Weight of 100 } \\
\text { berries } \mathbf{( g )}\end{array}$ & $\begin{array}{c}\text { Size of 100 } \\
\text { berries }\left(\mathbf{c m}^{3} \text { ) }\right.\end{array}$ & $\begin{array}{c}\text { Berry } \\
\text { diameter }(\mathbf{c m})\end{array}$ \\
\hline Control ( No fertilizers) & $533.11^{\mathrm{d}}$ & $439.0^{\mathrm{d}}$ & $483.3^{\mathrm{e}}$ & $1.51^{\mathrm{b}}$ \\
\hline Soil application of Ca & $570^{\mathrm{d}}$ & $681.3^{\mathrm{a}}$ & $750.0^{\mathrm{a}}$ & $1.80^{\mathrm{a}}$ \\
\hline Soil application K & $783.14^{\mathrm{a}}$ & $649.5^{\mathrm{ab}}$ & $675.0^{\mathrm{b}}$ & $1.673^{\mathrm{ab}}$ \\
\hline Soil application N & $706.70^{\mathrm{abc}}$ & $533.0^{\mathrm{c}}$ & $560.0^{\mathrm{cd}}$ & $1.63^{\mathrm{ab}}$ \\
\hline Foliar application of Ca & $740.00^{\mathrm{ab}}$ & $495.2^{\mathrm{cd}}$ & $538.3^{\mathrm{de}}$ & $1.73^{\mathrm{ab}}$ \\
\hline Grow more ${ }^{\mathrm{INC}}$ application & $633.32^{\mathrm{bcd}}$ & $599.3^{\mathrm{b}}$ & $623.5^{\mathrm{bc}}$ & $1.61^{\mathrm{ab}}$ \\
\hline Foliar application of $\mathrm{K}$ & $643.78^{\mathrm{bcd}}$ & $458.3^{\mathrm{d}}$ & $566.7^{\mathrm{cd}}$ & $1.75^{\mathrm{ab}}$ \\
\hline Foliar application of $\mathrm{Cu}$ & $616.80^{\text {cd }}$ & $520.0^{\mathrm{c}}$ & $578.3^{\mathrm{cd}}$ & $1.55^{\mathrm{ab}}$ \\
\hline
\end{tabular}

Note: All the values followed by the same letter in each column are not statistically different at $5 \%$ by LSD test. 
Table. 3. Effect of soil and foliar applications of some fertilizers on some chemical characteristics of the berries of table grape cv. Alkdarri.

\begin{tabular}{|c|c|c|c|}
\hline Treatments & $\begin{array}{l}\text { Berry firmness } \\
\quad\left(\mathrm{g} / \mathrm{cm}^{2}\right)\end{array}$ & pH of must & $\begin{array}{c}\text { Total soluble } \\
\text { solids (\%) }\end{array}$ \\
\hline Control ( No fertilizers) & $206.70^{c}$ & $3.39^{\mathrm{b}}$ & $15.53^{c}$ \\
\hline Soil application of $\mathrm{Ca}$ & $252.00^{\mathrm{abc}}$ & $3.39^{\mathrm{b}}$ & $17.00^{\mathrm{bc}}$ \\
\hline Soil application $\mathrm{K}$ & $276.00^{\mathrm{ab}}$ & $3.54^{\mathrm{a}}$ & $17.73^{\mathrm{b}}$ \\
\hline Soil application $\mathrm{N}$ & $226.72^{\mathrm{bc}}$ & $3.45^{\mathrm{ab}}$ & $17.17^{\mathrm{bc}}$ \\
\hline Foliar application of $\mathrm{Ca}$ & $267.36^{\mathrm{ab}}$ & $3.41^{b}$ & $16.67^{\mathrm{bc}}$ \\
\hline Foliar application of grow more ${ }^{\mathrm{INC}}$ & $228.70^{\mathrm{bc}}$ & $3.44^{\mathrm{ab}}$ & $16.50^{\mathrm{bc}}$ \\
\hline Foliar application of $\mathrm{K}$ & $287.33^{\mathrm{a}}$ & $3.39^{\mathrm{b}}$ & $15.97^{\mathrm{bc}}$ \\
\hline Foliar application of $\mathrm{Cu}$ & $264.69^{\mathrm{ab}}$ & $3.53^{\mathrm{a}}$ & $20.00^{\mathrm{a}}$ \\
\hline
\end{tabular}

Note: All the values followed by the same letter in each column are not statistically different at $5 \%$ by LSD test.

Sources of $\mathrm{Ca}, \mathrm{K}$ and $\mathrm{N}$ are calcium oxide $(27 \% \mathrm{Ca})$, potassium sulphate $(44 \% \mathrm{~K})$, and ammonium sulphate $(21 \% \mathrm{~N})$.

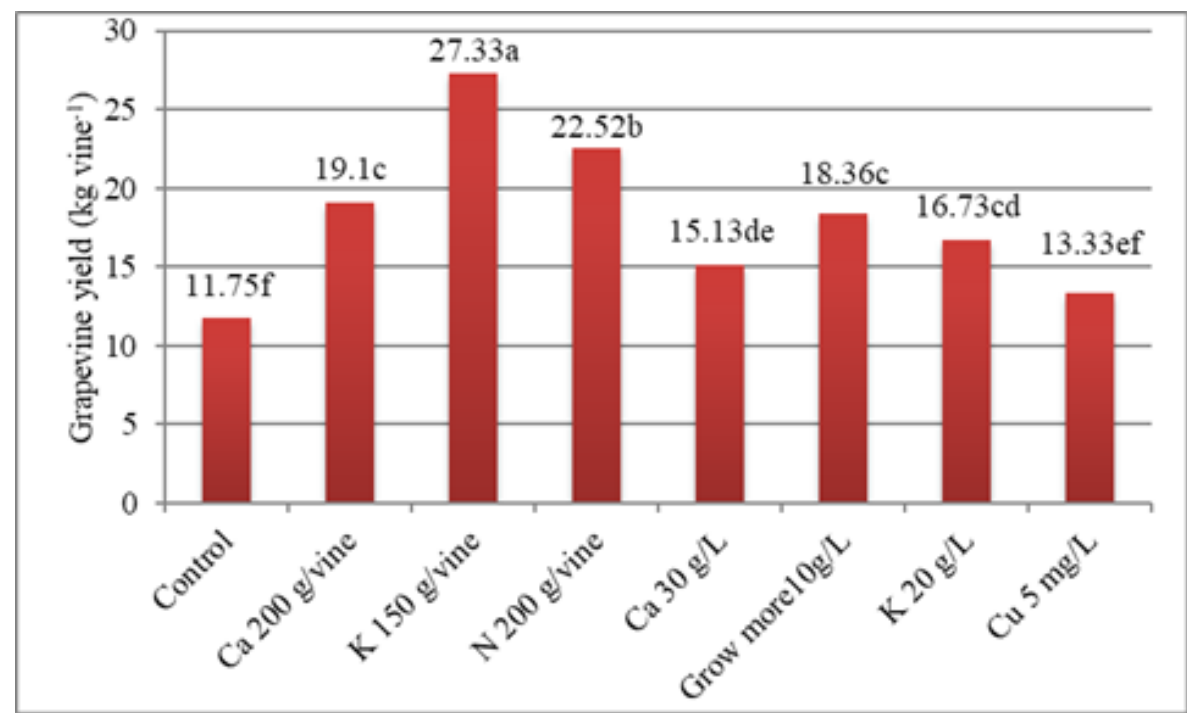

Figure 1. The effect of soil and foliar applications of fertilizers on table grape yield (kg/vine). All the values followed by the same letter in each column are not statistically different at $5 \%$ by LSD test

vine. There was no significant difference $(\mathrm{P}<0.05)$ between soil application of $\mathrm{N} 200 \mathrm{~g} / \mathrm{vine}$ and foliar application of $\mathrm{K} 10 \mathrm{~g} / \mathrm{L}$.

The pH value of must (grape juice): Data presented in (Tab. 3) shows that the highest $\mathrm{pH}$ was obtained in vines treated with foliar application of $\mathrm{Cu} 5 \mathrm{mg} / \mathrm{L}$. It was, however, not significantly higher than the control followed by soil application of K $150 \mathrm{~g} /$ vine, N $200 \mathrm{~g}$ /vine soil application, and Grow More ${ }^{\mathrm{INC}}$ fertilizer $10 \mathrm{~g} / \mathrm{L}$.
There was no significant difference between soil application of $\mathrm{K} 150 \mathrm{~g} / \mathrm{vine}$ and foliar application of $\mathrm{Cu} 5 \mathrm{mg} / \mathrm{L}$.

Total soluble solids (TSS): Data presented in (Tab. 3) indicates that the TSS was significantly affected by the fertilizer treatments, where the foliar application of $\mathrm{Cu} 5 \mathrm{mg} / \mathrm{L}$ produced the highest value, followed by vines receiving $\mathrm{K} 150 \mathrm{~g} /$ vine. There was no significant difference between soil application of K 150 g/vine, N 200 g/vine, Ca 
$30 \mathrm{~g} / \mathrm{L}$ foliar application, Grow More ${ }^{\mathrm{INC}}$ fertilizer $10 \mathrm{~g} / \mathrm{L}$, and foliar application of $\mathrm{K} 20 \mathrm{~g} / \mathrm{L}$ in TSS. Raath (2012) found that application of Kand Ca had little positive effect on the TSS of berries in table grapes. Abd El-Razek et al. (2011) reported that higher potassium supply significantly increased the total soluble solids in crimson seedless grapes.

Grapevine yield (kg/vine): The effect of soil and foliar fertilizers regarding the yield of grapevines is presented in (Figure 1). The data clearly indicates that potassium soil application of $\mathrm{K} 150 \mathrm{~g} /$ vine produced the highest significant differences when compared with other treatments followed by N $200 \mathrm{~g} /$ vine and Ca $200 \mathrm{~g} /$ vine. This treatment increased yield by $132.60 \%$, $91.66 \%$ and $62.55 \%$ as compared to the control respectively. Zlámalová et al. (2015) also found that foliar application of potassium increased grape yield in three-year trials. Also, EI-Boray et al. (1996) found that soil or foliar application during the two seasons increased grapevine yield. Huang et al. (2018) found that spraying 0.3 percent of the calcium nitrate solution increased fruit weight and fruit firmness in 'Ruby Seedless' grapes. Shedeed et al. (2019) found that grapes responded to fertigation with two potassium fertilizer treatments. Also, these may enhance nutrient content in grape plant tissues, promote the growth of grape plants and the yield of total and exportable fresh clusters.

\section{CONCLUSION}

Based on the results presented above, it can be concluded that foliar application of $\mathrm{K} 20 \mathrm{~g} / \mathrm{L}$ significantly enhanced berry firmness. Also, soil application of N $200 \mathrm{~g} /$ vine, $\mathrm{K} 150 \mathrm{~g} /$ vine, and Ca $200 \mathrm{~g} /$ vine significantly increased cluster weight, as well as the weight of 100 berries, the berry diameter, the size of 100 berries, and the yield per vine. The highest yield/vine was obtained from soil application of $\mathrm{K} 150 \mathrm{~g} / \mathrm{vine}$. The control displayed the lowest values of all studied parameters.

Acknowledgments. The authors would like to express their deep gratitude to the General Director of the National Agricultural Research Center (NARC) - Jordan for the technical support and assistance provided for the publication of this study. We are also thankful to NARC for the soil analysis and fruit chemical characteristics.
This research did not receive any specific grant from funding agencies in the public, commercial, or not-for-profit sectors.

\section{REFERENCES}

1. Abd El-Razek E, Treutter D, Saleh MMS, El-Shammaa M, Fouad, AA, Abdel-Hamid N (2011). Effect of nitrogen and potassium fertilization on productivity and fruit quality of 'crimson seedless' grape. Agriculture and Biology Journal of North America, 2(2): 330-340.

2. Birjely HMS, Al- Atrushy SMM (2017). Effect of some organic and non-Organic fertilizers on some parameters of growth and berries quality of grape cv. Kamali. Kufa Journal For Agricultural Sciences, 9(3): 262-274.

3. Dehnavard S, Souri MK, Mardanlu S (2017). Tomato growth responses to foliar application of ammonium sulfate in hydroponic culture. Journal of Plant Nutrition, 40(3): 315-323. Doi.org/10.1080/01904167.2016.1240 191.

4. Department of statistics. (2019). Available online at http://www.dos.gov.jo /accessed 10.03.2019.

5. EI·Boray MS, Fahmy MM, Iraqi MA, Abd EI·Latif L (1996). Effect of potassium soil and foliar fertilization on leaf potassium content, yield and berry qualities of Thompson seedless grape. Journal of Agricultural Science, Mansoura University, 21(3): 1153-1162.

6. Huang Y, Ma X, HU W, Wang J (2018). Effect of spraying calcium fertilizer on the fruit quality of 'Ruby Seedless' grape. $7^{\text {th }}$ International Conference on Energy and Environmental Protection published in Advances in Engineering Research, 170, 1564-1567.

7. OIV 2018, World Vitiviniculture Situation, OIV Statistical Report on World Vitiviniculture, International Organization of Vine and Wine, viewed 28 February 2017, available online at http://www.oiv.int

8. Mengel K, Kirkby EA (2001). Principles of plant nutrition. (5th ed.). Kluwer Academic Publishers, Amsterdam, Netherlands, p. 847.

9. Mohamadineia G, Farahi MH, Dastyaran M (2015). Foliar and soil drench application of humic acid on yield and berry properties of 'askari' grapevine. Agricultural Communications, 3(2): 21-27.

10. MSTAT-C (1991). A microcomputer program for design management and analysis of agronomic research experiments. Michigan State University. East Lansing, MI, USA.

11. Raath PJ (2012). Effect of varying levels of nitrogen, potassium and calcium nutrition on table grape vine physiology and berry quality. PhD thesis, Stellenbosch University, Department of Viticulture and Oenology, Faculty of AgriSciences, Stellenbosch, South Africa.

12. Rawashdeh H, Sala F (2015). Effect of some micronutrients on growth and yield of wheat and its leaves and grain content of iron and boron. Bulletin USAMV series Agriculture, 72(2): 504-508. DOI 10.15835/buasvmcnagr: 11334 .

13. Sala F, Dobrei A (2015). Managing the Yield and Quality of Grapes by Calcium Supplementing on Foliar Way. 
Bulletin USAMV series Horticulture, 72(2): 403-410. DOI:10.15835/buasvmcn-hort:11362.

14. Shedeed IS, Ahmed HK, Ahmed AI, Medhat KA (2019). Response of Grape Plants (Vitis vinifera L.) to Fertigation with Different Potassium Fertilizers under Egyptian Sandy Soil. Acta Scientific Agriculture, (3)5: 02-10.

15. Souri MK (2016). Aminochelate fertilizers: the new approach to the old problem; a review. Open Agriculture, 1(1): 118-123.

16. Souri MK., Hatamian M (2019). Aminochelates in plant nutrition; a review. Journal of Plant Nutrition, 42 (1): 6778.

17. Tohidloo G, Souri MK, Eskandarpour S (2018). Growth and fruit biochemical characteristics of three strawberry genotypes under different potassium concentrations of nutrient solution. Open Agriculture, 3(1): 356-362.

18. Zlámalová T, Elbl J, Baroň M, Bělíková H, Lampír L, Hlušek J, Lošák T (2015). Using foliar applications of magnesium and potassiumto improve yields and some qualitative parameters of vine grapes (Vitis vinifera L.). Plant Soil Environ., 61(10): 451-457. Doi.org/10.17221/437/2015PS.

19. Zivdar S, Arzani K, Souri MK, Moallemi N, Seyyednejad SM (2016). Physiological and biochemical response of olive (Olea europaea L.) cultivars to foliar potassium application. Journal of Agricultural Science and Technology, 18(7): 1897-1908. 